Qingjiong Zhang $\cdot$ Fareeha Zulfiqar $\cdot$ Xueshan Xiao

S. Amer Riazuddin · Radha Ayyagari · Farooq Sabar

Raphael Caruso $\cdot$ Paul A. Sieving $\cdot$ Sheikh Riazuddin

J. Fielding Hejtmancik

\title{
Severe autosomal recessive retinitis pigmentosa maps to chromosome 1p13.3-p21.2 between D1S2896 and D1S457 but outside ABCA4
}

Received: 17 May 2005/ Accepted: 3 August 2005/Published online: 28 September 2005

(C) Springer-Verlag 2005

Abstract A severe form of autosomal recessive retinitis pigmentosa (arRP) was identified in a large Pakistani family ascertained in the Punjab province of Pakistan. All affected individuals in the family had night blindness in early childhood, early complete loss of useful vision, and typical RP fundus changes plus macular degeneration. After exclusion of known arRP loci, a genomewide scan was performed using microsatellite markers at about $10 \mathrm{cM}$ intervals and calculating two-point lod scores. PCR cycle dideoxynucleotide sequencing was used to sequence candidate genes inside the linked region for mutations. RP in this family shows linkage to markers in a $10.5 \mathrm{cM}(8.9 \mathrm{Mbp})$ region of chromosome 1p13.3-p21.2 between D1S2896 and D1S457. D1S485 yields the highest lod score of 6.54 at $\theta=0$. Sequencing the exons and intron-exon boundaries of five candidate genes and six ESTs in this region, OLFM3, GNAI3, LOC126987, FLJ25070, DKFZp586G0123, AV729694,

Qingjiong Zhang, Fareeha Zulfiqar, Xueshan Xiao, Sheikh Riazuddin and J. Fielding Hejtmancik have contributed equally to this manuscript.

Q. Zhang $\cdot$ X. Xiao $\cdot$ S. Amer Riazuddin $\cdot$ R. Caruso

P. A. Sieving $\cdot$ J. Fielding Hejtmancik $(\square)$

Ophthalmic Genetics and Visual Function Branch, National Eye Institute, National Institutes of Health, Building 10, Room 10B10, 10 center Drive, MSC 1860, 20892-1860, Bethesda, MD USA E-mail: f3h@helix.nih.gov

Tel.: + 1-301-4968300

Fax: + 1-301-4351598

F. Zulfiqar · F. Sabar · S. Riazuddin

National Center of Excellence in Molecular Biology,

University of the Punjab, Lahore, Pakistan

Q. Zhang $\cdot$ X. Xiao

Zhongshan Ophthalmic Center, Sun Yat-sen University, Guangzhou, 510060, China

R. Ayyagari

Department of Ophthalmology and Visual Sciences, University of Michigan, 48105, Ann Arbor, MI USA
BU662869, BU656110, BU171991, BQ953690, and CA397743, did not identify any causative mutations. This novel locus lies approximately $4.9 \mathrm{cM}(7.1 \mathrm{Mbp})$ from $\mathrm{ABCA} 4$, which is excluded from the linked region. Identification and study of this gene may help to elucidate the phenotypic diversity of arRP mapping to this region.

\section{Introduction}

Retinitis pigmentosa (RP; OMIN268000) is a clinically and genetically heterogeneous group of progressive retinal degenerations primarily affecting rod photoreceptors. Clinically, they share common features including night blindness, gradual constriction of visual fields, typical fundus changes and loss of central vision (Heckenlively et al. 1988). RP is the most common hereditary retinal dystrophy causing irreversible blindness and is most frequently inherited as an autosomal recessive trait (Boughman et al. 1980; Buch et al. 2004). A number of loci or genes responsible for RP have been reported (RetNet: http://www.sph.uth.tmc.edu/Retnet/ disease.htm). arRP has been associated with 21 loci (Bareil et al. 2001; den Hollander et al. 1999; Dryja et al. 1995; Finckh et al. 1998; Gal et al. 2000; Gerber et al. 2000; $\mathrm{Gu}$ et al. 1999; Hagstrom et al. 1998; Hameed et al. 2001; Huang et al. 1995; Martinez-Mir et al. 1998; Maw et al. 1997; McLaughlin et al. 1993; Morimura et al. 1998, 1999; Nakazawa et al. 1998; Rivolta et al. 2000; Rosenfeld et al. 1992; Ruiz et al. 1998; Thompson et al. 2001; Tuson et al. 2004), and of these, the mutations responsible for arRP have been identified in ABCA4 (Martinez-Mir et al. 1998), CERKL (Tuson et al. 2004), CNGA1 (Dryja et al. 1995), CNGB1 (Bareil et al. 2001), CRB1 (den Hollander et al. 1999), LRAT (Thompson et al. 2001), MERTK (Gal et al. 2000), NR2E3 (Gerber et al. 2000), PDE6A (Huang et al. 1995), PDE6B (McLaughlin et al. 1993), 
RGR (Morimura et al. 1999), RHO (Rosenfeld et al. 1992), RLBP1 (Maw et al. 1997), RPE65 (Morimura et al. 1998), SAG (Nakazawa et al. 1998), TULP1 (Hagstrom et al. 1998), and USH2A (Rivolta et al. 2000).

The genes causing arRP in most families have yet to be identified. With the exception of USH2A, mutations in each individual gene identified so far have been responsible for arRP in only about $2-5 \%$ of families. Overall, causative mutations have been identified in a small fraction of arRP families, possibly as low as $30 \%$. The limited number of large families in which arRP is segregating has hindered the search for additional loci. Searching for additional loci and genes associated with arRP not only provides valuable information for the diagnosis and differentiation of retinal degenerations but also forms a scientific basis for their prevention and treatment. Identification of disease genes is also a valuable way to ascertain the function and physiological role of genes in the retina, especially for recessive diseases which generally are caused by the loss of gene function. Identification of genes and their physiological role in the retina is valuable especially for recessive diseases caused by loss of gene function.

In this study, we describe a large consanguineous family with severe form of arRP and map the disease to a novel locus on chromosome 1p between D1S2896 and D1S457. This region does not include the ABCA4 gene, which is proximal on chromosome 1 . In addition to the typical symptoms and signs of RP, affected individuals in this family showed relatively severe loss of central visual acuity in many affected individuals over 20 years old absent or limited only to hand movement. Consistent with this clinical finding, macular degeneration is present in all patients in whom the macular region is visible.

\section{Methods}

Family and clinical data

Family 61030 with arRP described in this study was ascertained from Punjab province of Pakistan as part of a collaborative project between the CEMB, Lahore, Pakistan and the NEI to identify genetic cause of eye diseases. It contains three consanguineous marriages. Nine affected and seven unaffected persons spanning three generations participated in this study. The diagnosis of RP was based on night blindness beginning in early childhood, progressive loss of peripheral vision, attenuation of retinal vessels, pigment disturbance on fundus examination, and decreasing visual acuity with age. Electroretinogram (ERG) responses were recorded consistent with ISCEV standards (Anonymous 1989) in selected cases, using commercial ERG equipment (LKC, Gaithersberg, MD, USA). Under scotopic (dark-adap- ted) conditions, the single bright-flash stimulus elicits a response dominated by rod activity but that also contains a cone component. The photopic (light-adapted) $30 \mathrm{~Hz}$ flicker stimulus elicits activity exclusively from the cone system. Ophthalmological examination was performed by Dr. Z.A. Qazi, Dr. M. Amer and Ms Fareeha Zulfiqar at the LRBT/CEMB, Lahore, Pakistan. Informed consent was obtained from all participating individuals, conforming to the tenets of the Declaration of Helsinki. This project was approved by the IRBs of the National Eye Institute, Bethesda, MD and the Centre of Excellence in Molecular Biology, Lahore, Pakistan.

\section{Genotyping and linkage analysis}

Genomic DNA was prepared from white blood cells as previously described (Smith et al. 1989). Genotyping for all participating family members was performed using $5^{6}$-fluorescently labeled microsatellite markers. A genome-wide scan was carried out using panels 1-27 of the ABI PRISM linkage Mapping Set Version 2, which includes 382 markers spaced at intervals of about $10 \mathrm{cM}$. PCR was conducted at $94^{\circ} \mathrm{C}$ for $8 \mathrm{~min}$, followed by 10 cycles of amplification at $94^{\circ} \mathrm{C} 15 \mathrm{~s}, 55^{\circ} \mathrm{C} 15 \mathrm{~s}$, and $72^{\circ} \mathrm{C}$ $30 \mathrm{~s}$; then 20 cycles at $89^{\circ} \mathrm{C} 15 \mathrm{~s}, 55^{\circ} \mathrm{C} 15 \mathrm{~s}, 72^{\circ} \mathrm{C} 30 \mathrm{~s}$; finally at $72^{\circ} \mathrm{C}$ for $10 \mathrm{~min}$. After mixing with GENESCAN $^{\mathrm{TM}} 400 \mathrm{HD}\left[\mathrm{ROX}^{\mathrm{TM}}\right]$ standard(ABI) and deionized formamide, PCR products were denatured at $95^{\circ} \mathrm{C}$ for $5 \mathrm{~min}$ and then immediately placed on ice for $5 \mathrm{~min}$. The amplicons were separated on Long Ranger sequencing gels (Cambrex) on an ABI 377 DNA sequencer. Genotyping data were collected by using GeneScan Analysis 3.0 and analyzed using the Genotyper 2.5 software package from ABI. Two-point linkage analysis was performed by using the MLINK program of the FASTLINK implementation of the LINKAGE program package (Lathrop and Lalouel 1984; Schaffer et al. 1994). RP in this family was analyzed as autosomal recessive trait with full penetrance and with a disease-gene allele frequency of 0.0001 . For fine mapping, the markers in the candidate region were arranged according to the National Center for Biotechnology Information (NCBI) map. Linkage analysis of family 61030 was carried out with three loops broken at individuals 5,15 , and 25 . Haplotypes were generated using the Cyrillic 2.1 program and confirmed by inspection. Equal marker allele frequencies were arbitrarily assumed for the genome wide scan and were calculated from 24 unrelated, unaffected individuals for fine mapping.

\section{Mutation screening of candidate genes}

Genes located in the linked region were selected for mutation screening based on (1) expression in the retina and/or RPE; (2) encoding a functional domain seen in 
known causative genes for RP; (3) belonging to a gene family known to cause RP; or (4) having a biochemical function related to a clinical phenotype that was observed in a syndrome with RP. Primers situated in the flanking region were designed to amplify each exon including exon-intron boundaries (primer sequences available on request). The amplicon was sequenced with the ABI BigDye Terminator cycle sequencing kit v3.1, according to the manufacturer's recommendations, using an ABI 3100 Genetic Analyzer. Sequencing results from 2 affected and 2 unaffected individuals (individual 12 (affected), individual 13 (unaffected), individual 16 (unaffected carrier), and individual 27 (affected)) in family 61030 as well as consensus sequences from the NCBI human genome database were imported to SeqMan (DNASTAR) and aligned to identify the variations.

Analysis of the ABCA4 gene for known sequence changes was carried out using the ABCA4 gene chip as described by Jaakson et al. (2003). Haplotypes were constructed with the sequence changes observed in the $\mathrm{ABCA} 4$ gene so as to minimize recombination events.

\section{Results}

The presenting symptom experienced by all nine affected individuals is night blindness, which appears at 310 years of age. Visual acuity gradually decreased accompanied by a progressive loss of peripheral vision. The visual acuity in eight of the nine affected individuals is severely limited, to hand movement in three cases, light perception in one case, and no light perception in four cases, even though they were only 22-47 years old (Table 1). The youngest affected boy (individual 17, 11 years old), had a visual acuity of 6/36 (right) and 6/48 (left).

Photophobia and nystagmus are reported in every patient recently examined. There is no evidence of keratoconus. Recent funduscopic examination reveals waxy-pale discs, obvious attenuation of the retinal arteries, a generalized grayish carpet-like retinal degeneration, and typical bone-spicule pigmentation in the mid-peripheral retina. The range and amount of pigmentation increased with age. Macular degeneration is seen in all affected individuals in whom the macular region is visible (Fig. 1). A bull's eye like appearance in the macular region surrounded by a grayish carpet-like retina in the posterior fundus was observed in younger patients as shown in Fig. 1: individuals 10, 11, 12, and 17. In older patients, the macular degeneration advanced to show atrophic changes accompanied by irregular pigment clumping as shown in Fig. 1: individuals 9, 14, and 30. ERG recordings document extensive loss of rod and cone function in two affected family members. Individual 10 at age 22 shows no appreciable rod or cone responses for either eye. Even individual 17 at age 11 has no identifiable cone responses to $30 \mathrm{~Hz}$ flicker and at best only slight residual rod function in only one eye. This indicates severe photoreceptor dysfunction and vision loss at young ages and indicates a severe form of rod-cone degeneration which has been termed "retinitis pigmentosa" (Fig. 2).

Initially, examining markers near known candidate genes excluded the RP locus in this family from all known arRP loci [data not shown]. Upon a complete genome-wide scan of chromosomes 1-22, two-point linkage analysis yields lod scores greater than 1.5 with markers corresponding to two possible loci, on chromosomes 1 and 13. The locus on chromosome 13 was excluded by lod scores of minus infinity of the nearby markers and by non-segregation of supposed disease alleles (haplotypes) in affected family members (data not show). Fine mapping and haplotype analysis confirms the locus on chromosome 1p13.2-p21.2 (Fig. 3, Table 2). This locus maps to a $10.5 \mathrm{cM}$ or $8.9 \mathrm{Mbp}$ region between D1S2896 and D1S457. All eight microsatellite markers examined inside this region generated positive lod scores, with D1S485 showing the highest lod score, 6.54 at $\theta=0$.

Haplotypes of family members in this region support the linkage results (Fig. 3). Recombination at D1S2896 in individual 27 with further recombination at D1S236 in individual 25 confirmed in individuals 30 and 31 set the telomeric boundary for the linked region at D1S2896. Recombination at D1S457 for individuals 12, 14 , and 15 , confirmed in individual 17 as well as lack of homozygosity for this marker in individual 17 sets the proximal boundary for the linked region. Of the infor-
Table 1 Clinical information for family members affected with arRP

\begin{tabular}{|c|c|c|c|c|c|c|c|c|c|}
\hline \multirow[t]{2}{*}{ ID \# } & \multirow[t]{2}{*}{ Gender } & \multirow{2}{*}{$\begin{array}{l}\text { Age } \\
\text { (years) }\end{array}$} & \multirow{2}{*}{ First symptom } & \multirow{2}{*}{$\begin{array}{l}\text { Age at } \\
\text { onset } \\
\text { (years) }\end{array}$} & \multirow{2}{*}{$\begin{array}{l}\text { Visual } \\
\text { acuity }\end{array}$} & \multicolumn{4}{|c|}{ Fundus changes } \\
\hline & & & & & & $\begin{array}{l}\text { Macular } \\
\text { degeneration }\end{array}$ & $\begin{array}{l}\text { Pale } \\
\text { optic } \\
\text { disc }\end{array}$ & $\begin{array}{l}\text { Artery } \\
\text { attenuation }\end{array}$ & $\begin{array}{l}\text { Pigment } \\
\text { deposit }\end{array}$ \\
\hline 9 & M & 32 & Night blindness & 8 & NPL & Yes & Yes & Yes & Yes \\
\hline 10 & $\mathrm{~F}$ & 22 & Night blindness & 10 & HM & Yes & Yes & Yes & Yes \\
\hline 11 & $\mathrm{~F}$ & 28 & Night blindness & 7 & HM & Yes & Yes & Yes & Yes \\
\hline 12 & $\mathrm{~F}$ & 26 & Night blindness & 9 & HM & Yes & Yes & Yes & Yes \\
\hline 14 & M & 30 & Night blindness & 8 & NPL & Yes & Yes & Yes & Yes \\
\hline 17 & M & 11 & Night blindness & 3 & $3 / 36,6 / 48$ & Yes & Yes & Yes & Yes \\
\hline 27 & M & 35 & Night blindness & 8 & NPL & Yes & Yes & Yes & Yes \\
\hline 30 & $\mathrm{~F}$ & 47 & Night blindness & 6 & NPL & Yes & Yes & Yes & Yes \\
\hline 31 & $\mathrm{~F}$ & 45 & Night blindness & 5 & PL & UN & UN & UN & Yes \\
\hline
\end{tabular}

$U N$ unknown. Posterior fundus could not be seen clearly because of posterior subcapsular cataract 


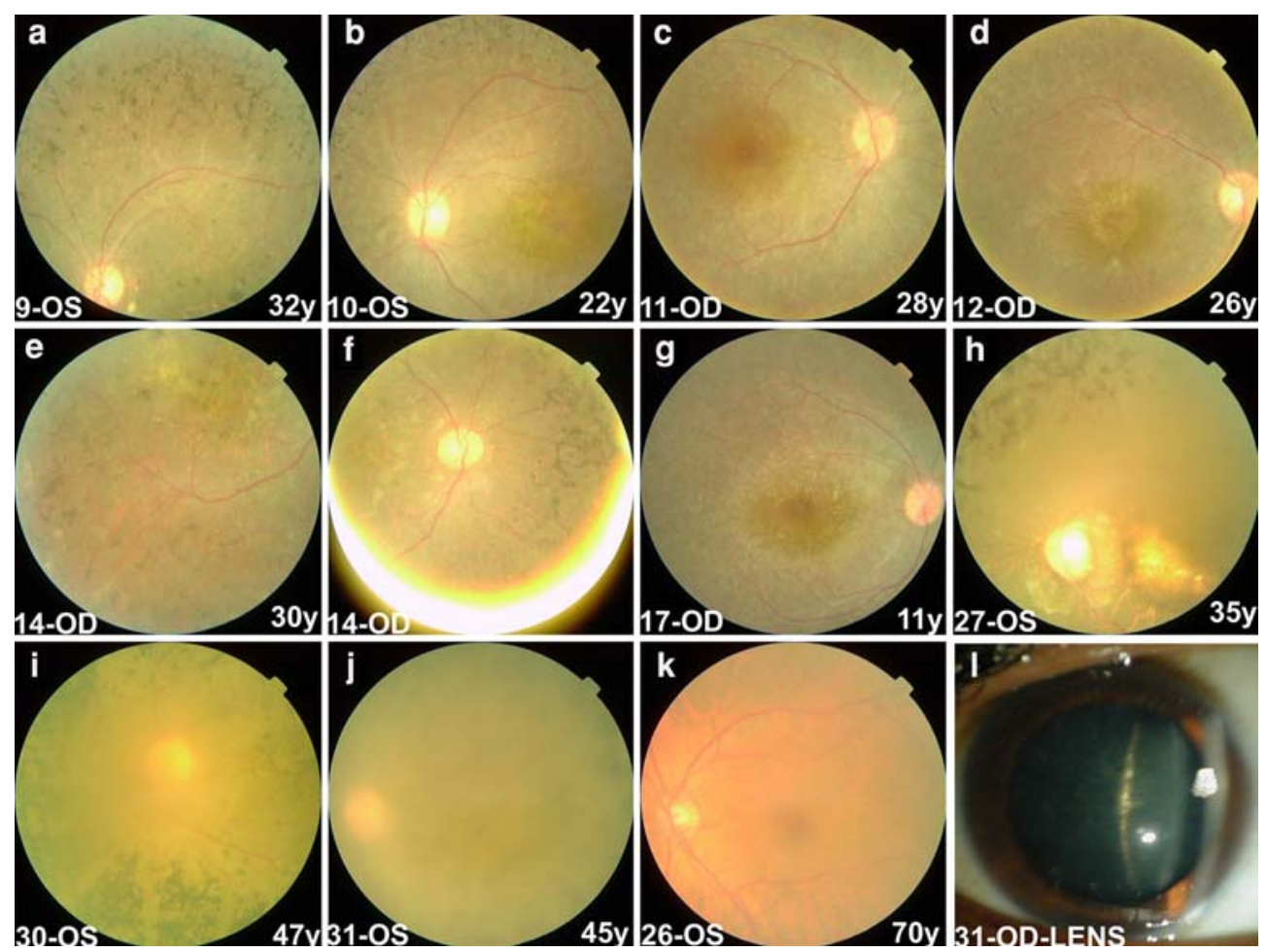

Fig. 1 Fundus photographs of all nine affected individuals and of a normal individual (26-OS) in the family as well as a photo showing posterior subcapsular cataract (31-lens). $O D$ right eye. $O S$ left eye. Grayish carpet-like retinal degeneration is shown in individuals 9, $10,11,12,14,17,27$, and 30 as compared to a normal fundus color in 26. Waxy-pale disc and arteriolar attenuation are shown in individuals 9, 10, 11,12,14,17, 27, and 30. Bone-spicule pigment deposit in mid-peripheral retina is shown in individuals $9,10,12$,

mative markers in the linked region, only D1S485 is homozygous in all affected individuals in both the left (offspring of individuals 5 and 6) and right (offspring of individuals 25 and 26) branches of the family. The variant affected haplotype inherited through individual 26 suggests an independent origin for the disease allele in that individual. Alternatively, if this disease allele in individual 26 is inherited from individual 40 or 41 , or in the more likely event that it represents inheritance of the same disease allele from an even more distant progenitor, the candidate locus might lie in a very small region (1 Mbp) around D1S485 between D1S2699 and D1S429. Unfortunately, only six ESTs and no identified genes reside in the $1 \mathrm{Mbp}$ region flanked by D1S2699 and D1S429.

The new arRP locus is close to ABCA4, which lies between D1S2868 and D1S236. ABCA4 is about 7.1 Mbp proximal to the new locus and is not linked with arRP in this family (Fig. 3 and Table 2). Recombination at D1S2896 in individual 27 with further recombination at D1S236 in individual 25 confirmed in individuals 30 and 31 exclude ABCA4 as a candidate locus. The linkage results are supported by haplotype analysis of SNPs within ABCA4 (Table 3). Individuals 9 and 17 , from the left-hand branch of the family, are
$14,27,30$, and 31. Such pigment deposit was recorded in 11 and 17 but is not shown in the photos because of further peripheral location. Bull's eye macular change is shown in individuals 10, 11, 12, and 17. Macular atrophy with pigment clumping is shown in individuals $9,14,27$, and 30 . The macular region is not visible for individual 31. The haze appearance of fundus photos for individuals 26, 27, 30, and 31 results from various degrees of posterior subcapsular cataract as shown in 31-lens

homozygous for one ABCA4 haplotype. In contrast, siblings 27 and 30 have inherited at least 3 distinct haplotypes, the data being consistent with these two siblings sharing one haplotype (shown on the right for these individuals in table 3), and no haplotype being identical to those in individuals 9 and 17. Similarly, recombination with D1S457, which is given as the proximal flanking marker for CORD8 by Khaliq et al. (2000), excludes CORD8 as a candidate locus, although CORD8 is also described as having a distinct phenotype.

There are over 73 genes listed in the linked region. Of these, 5 genes were selected for initial mutational screening based on their expression pattern and presumed functional properties. Genomic DNA encompassing the six ESTs between D1S2699 and D1S429 was also screened for mutation. Sequence analyses of LOC126987 (3 exons), FLJ25070 (14 exons), OLFM3 (6 exons), GNAI3 (8 exons), and DKFZp586G0123 (10 exons) as well as genomic DNA flanking six ESTs (AV729694, BU662869, BU656110, BU171991, BQ953690, and CA397743) did not reveal any potentially causative mutations. Both affected and unaffected family members are heterozygous for two SNPs in LOC126987, dbSNP2060700 and dbSNP6582952. No variation was detected in FLJ25070. Three individuals 
Fig. 2 ERG responses from two affected family members. For comparison, the normal control (ctr) subject to the scotopic single flash stimulus shows a rod-dominated initial negative-going a-wave and positive b-wave of $500 \mu \mathrm{V}$, and has a $120 \mu \mathrm{V}$ flicker response of the cone system to photopic $30 \mathrm{~Hz}$ stimulus

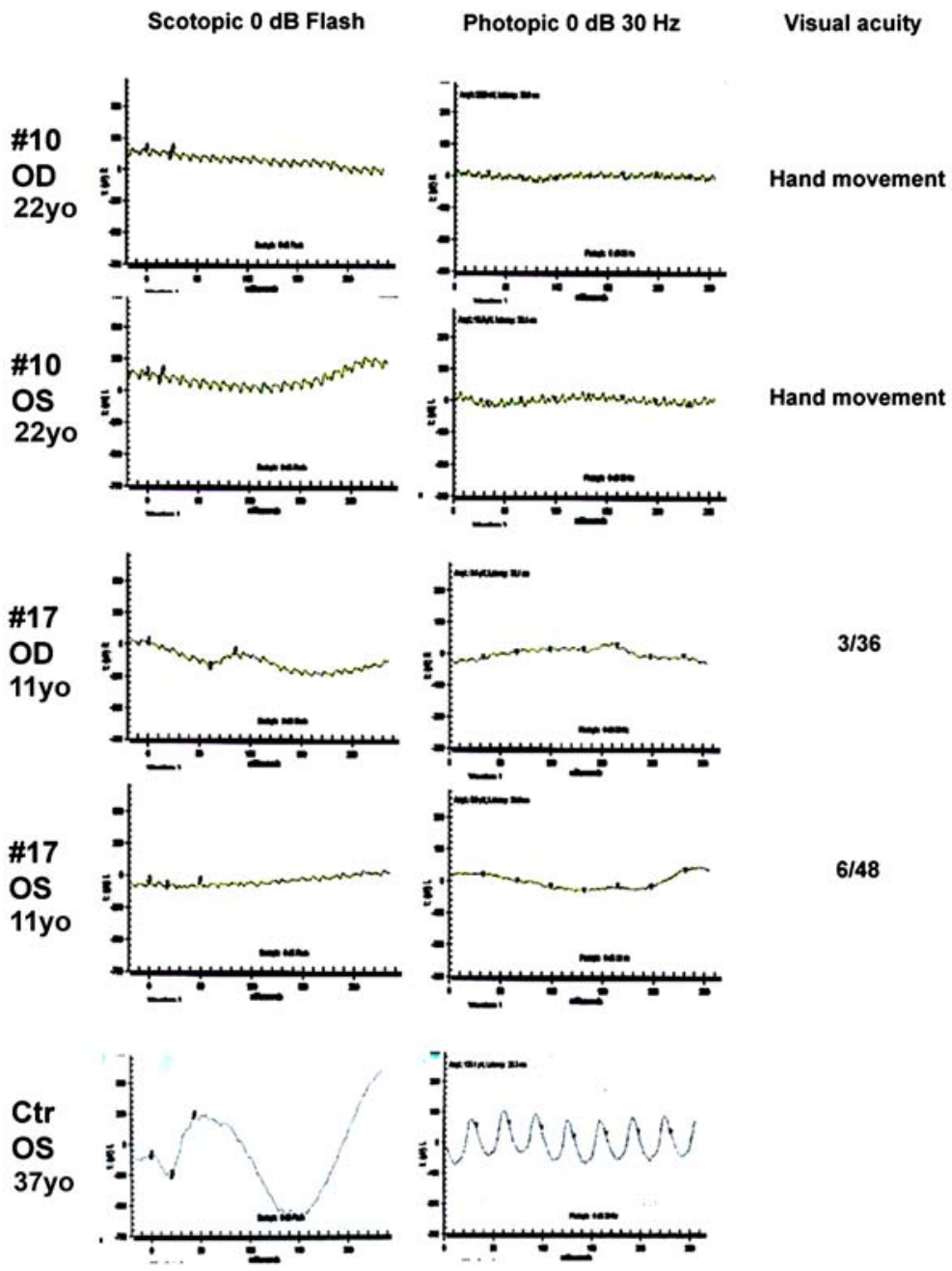

were each heterozygous for a SNP, dbSNP11276972, dbSNP10493973, and dbSNP4907955, in OLFM3. Both affected and unaffected individuals were homozygotes for three variations, c.311-11C $>\mathrm{T}$, c. $311-43 \mathrm{C}>\mathrm{T}$, and C.398 + 45T > C, in SLC25A24 (NM_013386).

\section{Discussion}

In this study, a severe type of arRP in a large Pakistani family with consanguinity was assigned to a new locus on 1p13.3-p21.2 between D1S2896 and D1S457. This interval does not include ABCA4, which was excluded by haplotype and linkage analysis producing lod scores below -2 (Table 2). Similarly, the CORD8 locus described by Khaliq and coworkers is distinct from this locus by linkage analysis (Khaliq et al. 2000). Five putative candidate genes and six ESTs in this interval have been screened by sequencing without identification of any potentially causative mutations. Nearly half of the 73 genes in the linked region are expressed in the retina and or retinal pigment epithelium (NCBI human genome database) and the function for many of them is currently unknown. Additional genes in the linked region include HEJ1, AMY2B, COL11A1, CESLR2, SORT1, GPR61, and GNAT2. Mutations in COL11A1 cause Stickler syndrome (Vikkula et al. 1995) and mutations in GNAT2 cause achromatopsia (Kohl et al. 2002). Identification of new gene structure of those retinally expressed EST sequences in the linked region and analysis of additional genes may finally lead to the target causative gene.

The RP disease phenotype in this family is quite severe for both rod and cone vision. All affected family members reported night blindness by age 10, and all have severe loss of central vision with reduction of visual acuity to "hand motion" or less at age $22-47$, and even the 11-year-old has severe acuity reduction. All including the 11-year-old had typical and advanced RP fundus changes accompanied by macular changes. The disease in this family is differentiated from the congenital blindness of Leber congenital amaurosis (OMIM 204000) in which patients generally are born blind or lose vision within a few months after birth. It is distinguished from most forms of cone-rod dystrophy in which visual function at night is spared initially and for 


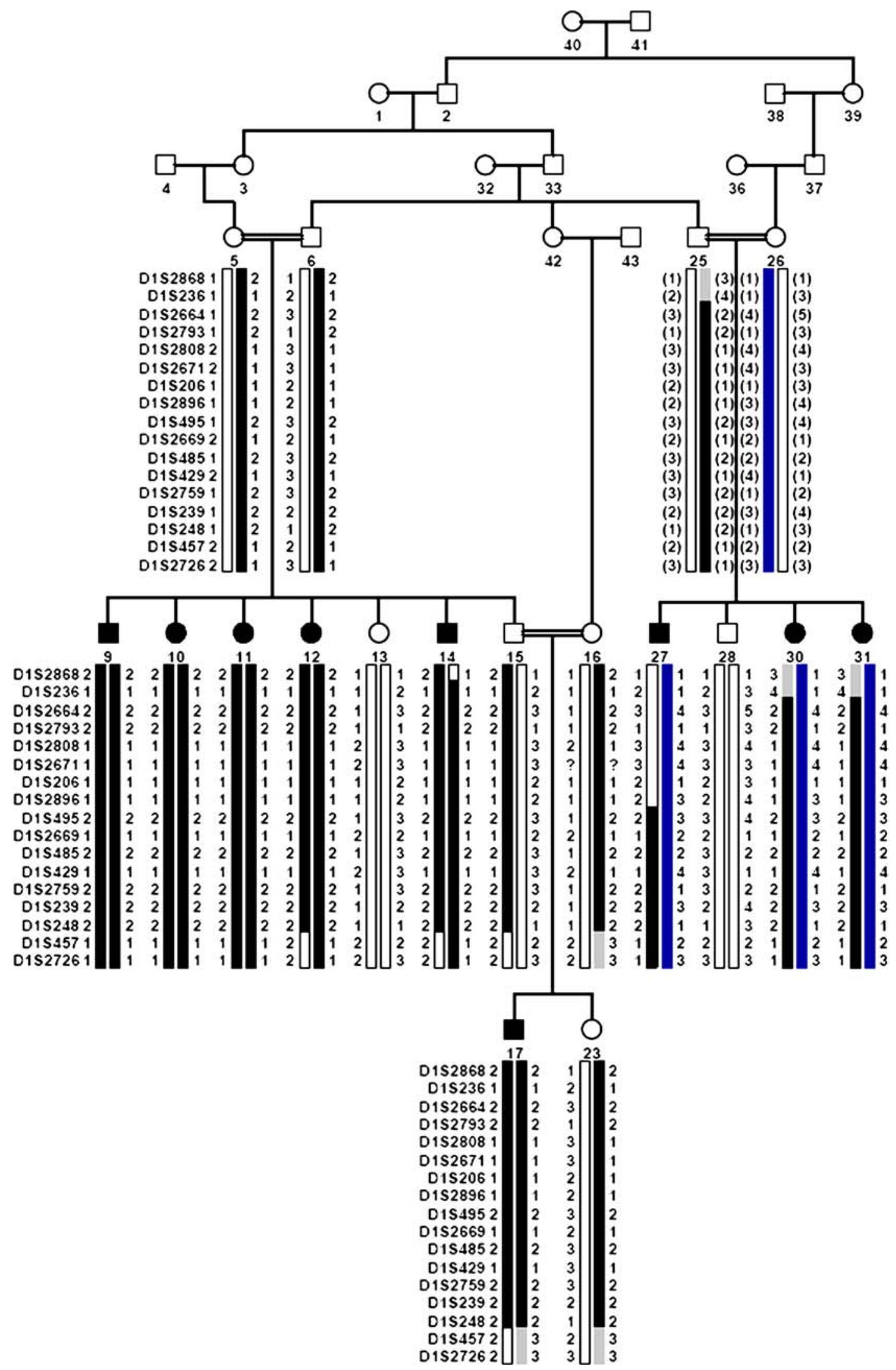

Fig. 3 Pedigree and haplotypes on 1p13-p21. Blackened bars indicate disease allele. Filled squares or filled circles represent individuals affected with RP. The individual number in the pedigree is the same as the number used in Fig. 1 and Table 3 
Table 2 Two-point linkage results for markers in the ARRP region at 1p13.2-p21.2

\begin{tabular}{|c|c|c|c|c|c|c|c|c|c|c|c|}
\hline \multirow[t]{2}{*}{ Markers } & \multicolumn{2}{|c|}{ Position } & \multicolumn{7}{|c|}{ Lod score at $\theta$ value } & \multirow[t]{2}{*}{$Z_{\max }$} & \multirow[t]{2}{*}{$\theta_{\max }$} \\
\hline & $\mathrm{cM}$ & $\mathrm{Mbp}^{\mathrm{a}}$ & 0.00 & 0.01 & 0.05 & 0.10 & 0.20 & 0.30 & 0.40 & & \\
\hline D1S2868 & 129.90 & 93.05 & $-\infty$ & -1.96 & 0.40 & 1.07 & 1.19 & 0.81 & 0.29 & 1.24 & 0.16 \\
\hline D1S236 & 132.40 & 93.82 & $-\infty$ & 1.03 & 2.07 & 2.22 & 1.88 & 1.27 & 0.56 & 2.22 & 0.10 \\
\hline D1S2664 & 133.00 & 95.66 & $-\infty$ & 2.91 & 3.81 & 3.78 & 3.06 & 2.01 & 0.86 & 3.85 & 0.07 \\
\hline D1S2793 & 133.00 & 96.81 & $-\infty$ & 3.26 & 4.14 & 4.08 & 3.29 & 2.17 & 0.96 & 4.17 & 0.07 \\
\hline D1S2808 & 135.20 & 98.97 & $-\infty$ & 2.33 & 3.25 & 3.25 & 2.62 & 1.70 & 0.69 & 3.30 & 0.07 \\
\hline D1S2671 & 137.40 & 100.98 & $-\infty$ & 3.47 & 4.34 & 4.29 & 3.48 & 2.34 & 1.07 & 4.38 & 0.07 \\
\hline D1S206 & 137.60 & 101.40 & $-\infty$ & 2.16 & 2.54 & 2.44 & 1.90 & 1.23 & 0.52 & 2.54 & 0.05 \\
\hline D1S2896 & 137.30 & 101.68 & $-\infty$ & 1.05 & 2.07 & 2.21 & 1.86 & 1.23 & 0.53 & 2.21 & 0.09 \\
\hline D1S495 & 140.80 & 102.27 & 3.35 & 4.57 & 4.76 & 4.42 & 3.39 & 2.17 & 0.93 & 4.80 & 0.03 \\
\hline D1S2699 & 140.70 & 104.49 & 1.52 & 2.77 & 3.06 & 2.86 & 2.14 & 1.29 & 0.46 & 3.06 & 0.04 \\
\hline D1S485 & 140.60 & 104.98 & 6.54 & 6.41 & 5.89 & 5.23 & 3.86 & 2.46 & 1.07 & 6.54 & 0.00 \\
\hline D1S429 & 140.50 & 105.41 & 3.70 & 4.90 & 5.06 & 4.68 & 3.56 & 2.25 & 0.94 & 5.11 & 0.03 \\
\hline D1S2759 & 140.30 & 105.56 & 3.70 & 5.25 & 5.41 & 5.01 & 3.85 & 2.49 & 1.09 & 5.46 & 0.03 \\
\hline D1S239 & 143.10 & 106.55 & 0.04 & 1.27 & 1.70 & 1.67 & 1.31 & 0.82 & 0.31 & 1.71 & 0.07 \\
\hline D1S248 & 143.30 & 106.87 & 3.41 & 4.63 & 4.82 & 4.48 & 3.45 & 2.23 & 0.97 & 4.85 & 0.04 \\
\hline D1S457 & 147.80 & 110.59 & $-\infty$ & -4.63 & -1.44 & -0.30 & 0.42 & 0.45 & 0.20 & 0.74 & 0.80 \\
\hline D1S2726 & 149.00 & 110.90 & $-\infty$ & -3.52 & -0.47 & 0.51 & 0.97 & 0.81 & 0.41 & 0.97 & 0.21 \\
\hline
\end{tabular}

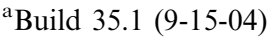

which some vision typically persists beyond the third to fourth decade (Evans et al. 1995; Gregory-Evans et al. 2000; Klevering et al. 1999; Small and Gehrs 1996). Like this family, macular degeneration in association with RP has been reported in arRP caused by mutations in such genes as MERTK (McHenry et al. 2004), RLBP1 (Burstedt et al. 2001) and ABCA4(Cremers et al. 1998; Martinez-Mir et al. 1997, 1998).

This new locus is of particular interest since it is close to but distinct from ABCA4, lying about $7.1 \mathrm{Mbp}$ telomeric. Mutations in the ABCA4 gene can cause autosomal recessive Stargardt disease (STGD)/fundus flavimaculatus (FFM), cone-rod dystrophy (CRD), and arRP (Allikmets et al. 1997; Briggs et al. 2001; Cremers et al. 1998; Fukui et al. 2002; Gerber et al. 1998; Klevering et al. 1999, 2004; Lewis et al. 1999; MartinezMir et al. 1998; Maugeri et al. 1999, 2000; Nasonkin et al. 1998; Paloma et al. 2002; Rozet et al. 1999; Rudolph et al. 2002; Shroyer et al. 2001; Webster et al.
2001). Two arRP families with macular degeneration and ABCA4 mutations were independently assigned to ABCA4 region by linkage studies for candidate loci (Cremers et al. 1998; Klevering et al. 1999; MartinezMir et al. 1997, 1998). In one family, five of the six affected individuals were homozygous for markers extending more centromerically without a determined border(Martinez-Mir et al. 1997). The second patients were classified as either RP- or CRD-like but were typical for neither disease. (Cremers et al. 1998; Klevering et al. 1999) The RP locus was found to lie between D1S198 and D1S239, containing ABCA4 and overlapping part of the new arRP locus determined in this study. The RP in the family reported here shares some common features with the two families linked to ABCA4: waxy-pale disc, attenuated retinal vessels, pigment deposits in the mid-peripheral retina, and degeneration or atrophy involving the macula. However, choroidal atrophy in the posterior pole is much more

Table 3 Haplotypes of four affected individuals in the pedigree using the sequence changes in the ABCA4 gene

\begin{tabular}{|c|c|c|c|c|c|c|}
\hline \multirow[t]{2}{*}{ Exon } & \multirow[t]{2}{*}{ Nucleotide change } & \multirow[t]{2}{*}{ Amino acid change } & \multicolumn{4}{|c|}{ Individual number } \\
\hline & & & 9 & 17 & 27 & 30 \\
\hline \multirow[t]{3}{*}{10} & $1268 \mathrm{~A}>\mathrm{G}$ & H423R & $A / A$ & $A / A$ & $A / A$ & $\mathrm{G} / \mathrm{A}$ \\
\hline & $1269 \mathrm{C}>\mathrm{T}$ & $\mathrm{H} 423 \mathrm{H}$ & $\mathrm{T} / \mathrm{T}$ & $\mathrm{T} / \mathrm{T}$ & $C / C$ & $\bar{C} / C$ \\
\hline & delG IVS + 5 & Splice & $\overline{G / G}$ & $\overline{G / G}$ & $\mathrm{G} / \mathrm{T}$ & $\mathrm{G} / \mathrm{T}$ \\
\hline 19 & $2828 \mathrm{G}>\mathrm{A}$ & R943Q & $\mathrm{A} / \mathrm{A}$ & $\mathrm{A} / \mathrm{A}$ & $\overline{G / G}$ & $\overline{G / G}$ \\
\hline 33 & $\mathrm{IVS}+48 \mathrm{C}>\mathrm{T}$ & Splice & $\overline{C / C}$ & $\overline{C / C}$ & $\mathrm{~T} / \mathrm{T}$ & $\mathrm{C} / \mathrm{T}$ \\
\hline 45 & $6249 \mathrm{C}>\mathrm{T}$ & I2083I & $C / C$ & $C / C$ & $\overline{\mathrm{T} / \mathrm{C}}$ & $\overline{C / C}$ \\
\hline 46 & $6285 \mathrm{~T}>\mathrm{C}$ & D2095D & $T / T$ & $T / T$ & $\mathrm{C} / \mathrm{T}$ & $T / T$ \\
\hline 48 & $6529 \mathrm{G}>\mathrm{A}$ & $\mathrm{D} 2177 \mathrm{~N}$ & $G / G$ & $G / G$ & $\overline{G / G}$ & $\mathbf{A} / \mathbf{G}$ \\
\hline 49 & $6764 \mathrm{G}>\mathrm{T}$ & S2255I & $G / G$ & $G / G$ & $\mathrm{~T} / \mathrm{G}$ & $G / G$ \\
\hline
\end{tabular}

Italic - wild-type alleles; underlined-nucleotide substitutions which do not lead to the amino acid substitution and/or common polymorphisms; bold - nucleotide substitution which results in an amino acid substitution; the individual numbers in Table 3 are consistent with those in Figs. 1 and 2 and Table 1 
obvious in the two families with ABCA4 mutations (Cremers et al. 1998; Klevering et al. 1999; MartinezMir et al. 1997, 1998). The generalized grayish carpetlike retinal change seen in this Pakistani family has also been reported previously in a family (Cremers et al. 1998; Klevering et al. 1999) in which the linked region also overlaps with the novel locus described here and which shows mutations in ABCA4.

It is not impossible that other factors may contribute to the phenotypic diversity of RP associated with ABCA4 mutations, and much evidence supports a complex relationship of arRP with mutations in ABCA4 (Cremers et al. 1998; Fukui et al. 2002; Klevering et al. 1999, 2004; Martinez-Mir et al. 1998; Paloma et al. 2002; Rozet et al. 1999; Rudolph et al. 2002; Shroyer et al. 2001). It has been hypothesized that two null mutations in ABCA4 result in arRP while a combination of a null mutation with a second mutation preserving residual ABCA4 function cause STGD or CRD (Cremers et al. 1998). However, homozygous null mutations and two null alleles have also been identified in patients with STGD and CRD (Briggs et al. 2001; Gerber et al. 1998; Lewis et al. 1999; Simonelli et al. 2004). Macular degeneration has been described in most RP patients with ABCA4 mutations (Cremers et al. 1998; Fukui et al. 2002; Klevering et al. 2004; Martinez-Mir et al. 1997, 1998). Some patients diagnosed as RP or RP-like had somewhat uncertain phenotypes (Klevering et al. 1999, 2004), or could not be excluded as having CRD (Klevering et al. 2004),or were actually diagnosed as having STGD (Fukui et al. 2002) or CRD (Paloma et al. 2002) in earlier examinations. The retinal degeneration seen in STGD and CRD could progress to show RP-like fundus changes (Fukui et al. 2002; Paloma et al. 2002). RP and STGD or CRD may present together in one family just by chance (Paloma et al. 2002). The high variability of ABCA4 is noteworthy, with an average of 3.8 variations per individual seen in all participants including controls and $76 \%$ of controls harboring at least one variation (Webster et al. 2001). Homozygous ABCA4 knock out mice still have ERG findings comparable to wild-type mice which is consistent with STGD but not RP (Radu et al. 2003; Weng et al. 1999). Therefore, it remains at least a theoretical possibility that another gene close to ABCA4 may cause RP independently or may act with ABCA4, contributing to the phenotypic diversity of ABCA4. The possibility is further suggested by the results presented in this study. Cloning of this new arRP gene linked to $1 \mathrm{p} 13.3-\mathrm{p} 21.2$ may elucidate this possibility.

Acknowledgements We are grateful to the families for their participation in this study. We sincerely thank the staff of Lyton Rehmatullah Benevolent Trust (LRBT) Hospital and in particular Dr. Z. A. Qazi and Dr. M. Amer for the identification of the families, their expert clinical evaluation of affected individual and for other help. We also thank Dr. Xiaodong Jiao, Ms. Afshan Yasmeen, Mr. M. Awais and Mr. Amer Niazi for their technical help. A part of the study carried out in Pakistan was supported by Higher Edu- cation Commission, Islamabad, Pakistan and Ministry of Science \& Technology, Islamabad, Pakistan. Dr. Qingjiong Zhang gratefully acknowledges the support from the National 863 Plan of China (Z19-01-04-02).

\section{References}

Anonymous (1989) Standard for clinical electroretinography. International Standardization Committee. Arch Ophthalmol 107:816-819

Allikmets R, Singh N, Sun H, Shroyer NF, Hutchinson A, Chidambaram A, Gerrard B, Baird L, Stauffer D, Peiffer A, Rattner A, Smallwood P, Li Y, Anderson KL, Lewis RA, Nathans J, Leppert M, Dean M, Lupski JR (1997) A photoreceptor cellspecific ATP-binding transporter gene (ABCR) is mutated in recessive Stargardt macular dystrophy. Nat Genet 15:236-246

Bareil C, Hamel CP, Delague V, Arnaud B, Demaille J, Claustres M (2001) Segregation of a mutation in CNGB1 encoding the betasubunit of the rod cGMP-gated channel in a family with autosomal recessive retinitis pigmentosa. Hum Genet 108:328-334

Boughman JA, Conneally PM, Nance W (1980) Population genetic studies of retinitis pigmentosa. Am J Hum Genet 32:223-225

Briggs CE, Rucinski D, Rosenfeld PJ, Hirose T, Berson EL, Dryja TP (2001) Mutations in ABCR (ABCA4) in patients with Stargardt macular degeneration or cone-rod degeneration. Invest Ophthalmol Vis Sci 42:2229-2236

Buch H, Vinding T, La Cour M, Appleyard M, Jensen GB, Nielsen NV (2004) Prevalence and causes of visual impairment and blindness among 9980 Scandinavian adults: the Copenhagen City Eye Study. Ophthalmology 111:53-61

Burstedt MS, Forsman-Semb K, Golovleva I, Janunger T, Wachtmeister L, Sandgren O (2001) Ocular phenotype of bothnia dystrophy, an autosomal recessive retinitis pigmentosa associated with an R234W mutation in the RLBP1 gene. Arch Ophthalmol 119:260-267

Cremers FP, van de Pol DJ, van Driel M, den Hollander AI, van Haren FJ, Knoers NV, Tijmes N, Bergen AA, Rohrschneider $\mathrm{K}$, Blankenagel A, Pinckers AJ, Deutman AF, Hoyng CB (1998) Autosomal recessive retinitis pigmentosa and cone-rod dystrophy caused by splice site mutations in the Stargardt's disease gene ABCR. Hum Mol Genet 7:355-362

den Hollander AI, ten Brink JB, de Kok YJ, van Soest S, van den Born LI, van Driel MA, van de Pol DJ, Payne AM, Bhattacharya SS, Kellner U, Hoyng CB, Westerveld A, Brunner HG, Bleeker-Wagemakers EM, Deutman AF, Heckenlively JR, Cremers FP, Bergen AA (1999) Mutations in a human homologue of Drosophila crumbs cause retinitis pigmentosa (RP12). Nat Genet 23:217-221

Dryja TP, Finn JT, Peng YW, McGee TL, Berson EL, Yau KW (1995) Mutations in the gene encoding the alpha subunit of the rod cGMP-gated channel in autosomal recessive retinitis pigmentosa. Proc Natl Acad Sci USA 92:10177-10181

Evans K, Duvall-Young J, Fitzke FW, Arden GB, Bhattacharya SS, Bird AC (1995) Chromosome 19q cone-rod retinal dystrophy. Ocular phenotype. Arch Ophthalmol 113:195-201

Finckh U, Xu S, Kumaramanickavel G, Schurmann M, Mukkadan JK, Fernandez ST, John S, Weber JL, Denton MJ, Gal A (1998) Homozygosity mapping of autosomal recessive retinitis pigmentosa locus (RP22) on chromosome 16p12.1-p12.3. Genomics 48:341-345

Fukui T, Yamamoto S, Nakano K, Tsujikawa M, Morimura H, Nishida K, Ohguro N, Fujikado T, Irifune M, Kuniyoshi K, Okada AA, Hirakata A, Miyake Y, Tano Y (2002) ABCA4 gene mutations in Japanese patients with Stargardt disease and retinitis pigmentosa. Invest Ophthalmol Vis Sci 43:2819 2824

Gal A, Li Y, Thompson DA, Weir J, Orth U, Jacobson SG, Apfelstedt-Sylla E, Vollrath D (2000) Mutations in MERTK, the human orthologue of the RCS rat retinal dystrophy gene, cause retinitis pigmentosa. Nat Genet 26:270-271 
Gerber S, Rozet JM, van de Pol TJ, Hoyng CB, Munnich A, Blankenagel A, Kaplan J, Cremers FP (1998) Complete exonintron structure of the retina-specific ATP binding transporter gene (ABCR) allows the identification of novel mutations underlying Stargardt disease. Genomics 48:139-142

Gerber S, Rozet JM, Takezawa SI, dos Santos LC, Lopes L, Gribouval O, Penet C, Perrault I, Ducroq D, Souied E, Jeanpierre M, Romana S, Frezal J, Ferraz F, Yu-Umesono R, Munnich A, Kaplan J (2000) The photoreceptor cell-specific nuclear receptor gene (PNR) accounts for retinitis pigmentosa in the Crypto-Jews from Portugal (Marranos), survivors from the Spanish Inquisition. Hum Genet 107:276284

Gregory-Evans K, Kelsell RE, Gregory-Evans CY, Downes SM, Fitzke FW, Holder GE, Simunovic M, Mollon JD, Taylor R, Hunt DM, Bird AC, Moore AT (2000) Autosomal dominant cone-rod retinal dystrophy (CORD6) from heterozygous mutation of GUCY2D, which encodes retinal guanylate cyclase. Ophthalmology 107:55-61

Gu S, Kumaramanickavel G, Srikumari CR, Denton MJ, Gal A (1999) Autosomal recessive retinitis pigmentosa locus RP28 maps between D2S1337 and D2S286 on chromosome 2p11-p15 in an Indian family. J Med Genet 36:705-707

Hagstrom SA, North MA, Nishina PL, Berson EL, Dryja TP (1998) Recessive mutations in the gene encoding the tubby-like protein TULP1 in patients with retinitis pigmentosa. Nat Genet 18:174-176

Hameed A, Khaliq S, Ismail M, Anwar K, Mehdi SQ, Bessant D, Payne AM, Bhattacharya SS (2001) A new locus for autosomal recessive RP (RP29) mapping to chromosome 4q32-q34 in a Pakistani family. Invest Ophthalmol Vis Sci 42:1436-1438

Heckenlively JR, Yoser SL, Friedman LH, Oversier JJ (1988) Clinical findings and common symptoms in retinitis pigmentosa. Am J Ophthalmol 105:504-511

Huang SH, Pittler SJ, Huang X, Oliveira L, Berson EL, Dryja TP (1995) Autosomal recessive retinitis pigmentosa caused by mutations in the alpha subunit of rod cGMP phosphodiesterase. Nat Genet 11:468-471

Jaakson K, Zernant J, Kulm M, Hutchinson A, Tonisson N, Glavac D, Ravnik-Glavac M, Hawlina M, Meltzer MR, Caruso RC, Testa F, Maugeri A, Hoyng CB, Gouras P, Simonelli F, Lewis RA, Lupski JR, Cremers FP, Allikmets R (2003) Genotyping microarray (gene chip) for the ABCR (ABCA4) gene. Hum Mutat 22:395-403

Khaliq S, Hameed A, Ismail M, Anwar K, Leroy BP, Mehdi SQ, Payne AM, Bhattacharya SS (2000) Novel locus for autosomal recessive cone-rod dystrophy CORD8 mapping to chromosome 1q12-Q24. Invest Ophthalmol Vis Sci 41:3709-3712

Klevering BJ, van Driel M, van de Pol DJ, Pinckers AJ, Cremers FP, Hoyng CB (1999) Phenotypic variations in a family with retinal dystrophy as result of different mutations in the ABCR gene. Br J Ophthalmol 83:914-918

Klevering BJ, Maugeri A, Wagner A, Go SL, Vink C, Cremers FP, Hoyng CB (2004) Three families displaying the combination of Stargardt's disease with cone-rod dystrophy or retinitis pigmentosa. Ophthalmology 111:546-553

Kohl S, Baumann B, Rosenberg T, Kellner U, Lorenz B, Vadala M, Jacobson SG, Wissinger B (2002) Mutations in the cone photoreceptor G-protein alpha-subunit gene GNAT2 in patients with achromatopsia. Am J Hum Genet 71:422-425

Lathrop GM, Lalouel JM (1984) Easy calculations of lod scores and genetic risks on small computers. Am J Hum Genet 36:460-465

Lewis RA, Shroyer NF, Singh N, Allikmets R, Hutchinson A, Li Y, Lupski JR, Leppert M, Dean M (1999) Genotype/Phenotype analysis of a photoreceptor-specific ATP-binding cassette transporter gene, ABCR, in Stargardt disease. Am J Hum Genet 64:422-434

Martinez-Mir A, Bayes M, Vilageliu L, Grinberg D, Ayuso C, del Rio T, Garcia-Sandoval B, Bussaglia E, Baiget M, GonzalezDuarte R, Balcells S (1997) A new locus for autosomal recessive retinitis pigmentosa (RP19) maps to $1 \mathrm{p} 13-1 \mathrm{p} 21$. Genomics $40: 142-146$
Martinez-Mir A, Paloma E, Allikmets R, Ayuso C, del Rio T, Dean M, Vilageliu L, Gonzalez-Duarte R, Balcells S (1998) Retinitis pigmentosa caused by a homozygous mutation in the Stargardt disease gene ABCR. Nat Genet 18:11-12

Maugeri A, van Driel MA, van de Pol DJ, Klevering BJ, van Haren FJ, Tijmes N, Bergen AA, Rohrschneider K, Blankenagel A, Pinckers AJ, Dahl N, Brunner HG, Deutman AF, Hoyng CB, Cremers FP (1999) The $2588 \mathrm{G}->\mathrm{C}$ mutation in the ABCR gene is a mild frequent founder mutation in the Western European population and allows the classification of ABCR mutations in patients with Stargardt disease. Am J Hum Genet 64:1024-1035

Maugeri A, Klevering BJ, Rohrschneider K, Blankenagel A, Brunner HG, Deutman AF, Hoyng CB, Cremers FP (2000) Mutations in the ABCA4 (ABCR) gene are the major cause of autosomal recessive cone-rod dystrophy. Am J Hum Genet 67:960-966

Maw MA, Kennedy B, Knight A, Bridges R, Roth KE, Mani EJ, Mukkadan JK, Nancarrow D, Crabb JW, Denton MJ (1997) Mutation of the gene encoding cellular retinaldehyde-binding protein in autosomal recessive retinitis pigmentosa. Nat Genet 17:198-200

McHenry CL, Liu Y, Feng W, Nair AR, Feathers KL, Ding X, Gal A, Vollrath D, Sieving PA, Thompson DA (2004) MERTK arginine-844-cysteine in a patient with severe rod-cone dystrophy: loss of mutant protein function in transfected cells. Invest Ophthalmol Vis Sci 45:1456-1463

McLaughlin ME, Sandberg MA, Berson EL, Dryja TP (1993) Recessive mutations in the gene encoding the beta-subunit of rod phosphodiesterase in patients with retinitis pigmentosa. Nat Genet 4:130-134

Morimura H, Fishman GA, Grover SA, Fulton AB, Berson EL, Dryja TP (1998) Mutations in the RPE65 gene in patients with autosomal recessive retinitis pigmentosa or leber congenital amaurosis. Proc Natl Acad Sci USA 95:3088-3093

Morimura H, Saindelle-Ribeaudeau F, Berson EL, Dryja TP (1999) Mutations in RGR, encoding a light-sensitive opsin homologue, in patients with retinitis pigmentosa. Nat Genet 23:393-394

Nakazawa M, Wada Y, Tamai M (1998) Arrestin gene mutations in autosomal recessive retinitis pigmentosa. Arch Ophthalmol 116:498-501

Nasonkin I, Illing M, Koehler MR, Schmid M, Molday RS, Weber BH (1998) Mapping of the rod photoreceptor ABC transporter (ABCR) to 1p21-p22.1 and identification of novel mutations in Stargardt's disease. Hum Genet 102:21-26

Paloma E, Coco R, Martinez-Mir A, Vilageliu L, Balcells S, Gonzalez-Duarte R (2002) Analysis of ABCA4 in mixed Spanish families segregating different retinal dystrophies. Hum Mutat 20:476

Radu RA, Mata NL, Nusinowitz S, Liu X, Sieving PA, Travis GH (2003) Treatment with isotretinoin inhibits lipofuscin accumulation in a mouse model of recessive Stargardt's macular degeneration. Proc Natl Acad Sci USA 100:4742-4747

Rivolta C, Sweklo EA, Berson EL, Dryja TP (2000) Missense mutation in the USH2A gene: association with recessive retinitis pigmentosa without hearing loss. Am J Hum Genet 66:1975-1978

Rosenfeld PJ, Cowley GS, McGee TL, Sandberg MA, Berson EL, Dryja TP (1992) A null mutation in the rhodopsin gene causes rod photoreceptor dysfunction and autosomal recessive retinitis pigmentosa. Nat Genet 1:209-213

Rozet JM, Gerber S, Ghazi I, Perrault I, Ducroq D, Souied E, Cabot A, Dufier JL, Munnich A, Kaplan J (1999) Mutations of the retinal specific ATP binding transporter gene (ABCR) in a single family segregating both autosomal recessive retinitis pigmentosa RP19 and Stargardt disease: evidence of clinical heterogeneity at this locus. J Med Genet 36:447-451

Rudolph G, Kalpadakis P, Haritoglou C, Rivera A, Weber BH (2002) [Mutations in the ABCA4 gene in a family with Stargardt's disease and retinitis pigmentosa (STGD1/RP19)]. Klin Monatsbl Augenheilkd 219:590-596 
Ruiz A, Borrego S, Marcos I, Antinolo G (1998) A major locus for autosomal recessive retinitis pigmentosa on $6 \mathrm{q}$, determined by homozygosity mapping of chromosomal regions that contain gamma-aminobutyric acid-receptor clusters. Am J Hum Genet 62:1452-1459

Schaffer AA, Gupta SK, Shriram K, Cottingham RW (1994) Avoiding recomputation in genetic linkage analysis. Hum Hered 44:225-237

Shroyer NF, Lewis RA, Yatsenko AN, Lupski JR (2001) Null missense ABCR (ABCA4) mutations in a family with stargardt disease and retinitis pigmentosa. Invest Ophthalmol Vis Sci 42:2757-2761

Simonelli F, Testa F, Zernant J, Nesti A, Rossi S, Rinaldi E, Allikmets R (2004) Association of a homozygous nonsense mutation in the ABCA4 (ABCR) gene with cone-rod dystrophy phenotype in an Italian family. Ophthalmic Res 36:82-88

Small KW, Gehrs K (1996) Clinical study of a large family with autosomal dominant progressive cone degeneration. Am J Ophthalmol 121:1-12

Smith RJH, Holcomb JD, Daiger SP, Caskey CT, Pelias MZ, Alford BR, Fontenot DD, Hejtmancik JF (1989) Exclusion of Usher syndrome gene from much of chromosome 4. Cytogenet Cell Genet 50:102-106
Thompson DA, Li Y, McHenry CL, Carlson TJ, Ding X, Sieving PA, Apfelstedt-Sylla E, Gal A (2001) Mutations in the gene encoding lecithin retinol acyltransferase are associated with early-onset severe retinal dystrophy. Nat Genet 28:123-124

Tuson M, Marfany G, Gonzalez-Duarte R (2004) Mutation of CERKL, a novel human ceramide kinase gene, causes autosomal recessive retinitis pigmentosa (RP26). Am J Hum Genet $74: 128-138$

Vikkula M, Mariman EC, Lui VC, Zhidkova NI, Tiller GE, Goldring MB, van Beersum SE, Waal Malefijt MC, van den Hoogen FH, Ropers HH, . (1995) Autosomal dominant and recessive osteochondrodysplasias associated with the COL11A2 locus. Cell 80:431-437

Webster AR, Heon E, Lotery AJ, Vandenburgh K, Casavant TL, Oh KT, Beck G, Fishman GA, Lam BL, Levin A, Heckenlively JR, Jacobson SG, Weleber RG, Sheffield VC, Stone EM (2001) An analysis of allelic variation in the ABCA4 gene. Invest Ophthalmol Vis Sci 42:1179-1189

Weng J, Mata NL, Azarian SM, Tzekov RT, Birch DG, Travis GH (1999) Insights into the function of Rim protein in photoreceptors and etiology of Stargardt's disease from the phenotype in abcr knockout mice. Cell 98:13-23 